Bridi, M. E., Ceolin, E. D., Granja, A. D., and Formoso, C. T. (2019). "Modularity in the Construction Industry: A Systematic Mapping Study." In: Proc. $27^{\text {th }}$ Annual Conference of the International. Group for Lean Construction (IGLC), Pasquire C. and Hamzeh F.R. (ed.), Dublin, Ireland, pp. 737-748. DOI: https://doi.org/10.24928/2019/0178. Available at: <www.iglc.net>.

\title{
MODULARITY IN THE CONSTRUCTION INDUSTRY: A SYSTEMATIC MAPPING STUDY
}

\author{
Marcelle Engler Bridi ${ }^{1}$, Eliká Deboni Ceolin², Ariovaldo Denis Granja ${ }^{\mathbf{3}}$, \\ and Carlos Torres Formoso ${ }^{4}$
}

\begin{abstract}
Modularity is a concept that has not been fully explored in the construction industry, as a mechanism to improve cost, quality, and schedule performance. However, currently it is strongly related to the idea of developing mass customized innovative products. Although modularization is widely used in the manufacturing industry, its application in construction-related opportunities seems to be difficult. This paper presents a Systematic Mapping Study (SMS) on the use of modularity in the construction industry, and attempts to make a connection with Lean principles. SMS is a research method that aims to provide an overview of a specific area, through systematic selection and analysis of the literature, starting from a research question. The steps used to conduct this research work are described, as well as the mapping of the topic areas already covered in literature. The main contribution of the paper is concerned with the connections between Modularity core ideas and Lean principles.
\end{abstract}

\section{KEYWORDS}

Modularity; Lean Supply Chain; Lean Principles; Systematic Mapping Study.

\section{INTRODUCTION}

Modularity can be defined as the degree to which a system can be divided into subunits (modules) that can be joined and recombined in different ways (Simon 1991; Schilling

1 Ph.D. Student, Construction Management Research Laboratory (LAGERCON), School of Civil Engineering, Architecture and Urban Design, University of Campinas, Campinas, SP, Brazil, marcelle.bridi@gmail.com

2 Ph.D. Student, Building Innovation Research Unit (NORIE), Universidade Federal do Rio Grande do Sul, Porto Alegre 90035-190, Brazil, elikac@ gmail.com

3 Associate Professor, Architecture and Construction Dept., Director of the Construction Management Research Laboratory (LAGERCON), School of Civil Engineering, Architecture and Urban Design, University of Campinas, 951 Albert Einstein Ave, P.O. Box 6021, Campinas, SP 13083-852, Brazil, Phone: +55 19 3788-2082, adgranja@ fec.unicamp.br

4 Building Innovation Research Unit (NORIE), School of Engineering, Universidade Federal do Rio Grande do Sul, Porto Alegre 90035-190, Brazil; formoso@ufrgs.br 
2000). A module is understood as an independent unit, which has its own functionality, and standardized interfaces that interact according to the systems' definition (Miller and Elgard 1998).

Although some characteristics of the construction industry make it difficult the adoption of modularity in some construction projects, there are potential benefits for its implementation (Doran and Giannakis 2011). Modular buildings can contribute to increase efficiency and improve cost performance, bringing a quick return on project's investment, which may be an important factor to justify their adoption by the construction companies (Moghadam et al. 2012). However, there is still a lack of construction management studies that clearly address the complexity and scope of a modular application (Gosling et al. 2016).

Some empirical studies in the construction industry point out that there are different types of modularity: product, process, and supply chain modularities (Voordijk et al. 2006; Lessing 2006, Viana et al. 2016, Peltokorpi et al. 2018).

First, the product modularity occurs when the product is decoupled into parts and components (Gershenson et al. 2003). The idea is that a limited number of modules can be combined to produce a wide variety of products (Miller and Elgard 1998, Gosling et al. 2016). Unlike an integral product, a modular product has interchangeable components that have one or only a few functions (Voordijk et al. 2006). Also, the adoption of modularity facilitates the replacement or upgrading of individual components, supporting the development of innovations (Lennartson and Björnfot 2010). Therefore, the use of modularization can go beyond improving the time, cost and quality performance of the project. It can potentially enable the development of innovative products and create flexibility during the use and maintenance stages (Peltokorpi et al. 2018). In addition, several studies point to modularity as a strategy to deliver a customized product to clients (Miller and Elgard 1998, da Rocha 2011, Peltokorpi et al. 2018).

Second, the process modularity is concerned with the adoption of standardized operations with shared interfaces (Lennartson and Björnfot 2010). However, a modular process does not necessarily include standardized components, but rather standardized manufacturing, delivery, and assembly processes (Peltokorpi et al. 2018). Furthermore, a modular process allows the sharing of production technologies, parallel assembly, and the use of standardized work (Lennartson and Björnfot 2010).

The third category of modularity is related to the configuration of the supply chain, which can be defined as a network of companies that transform raw material into supplies, products, or modules, including its distribution (Cheng et al 2010). In construction supply chains, some transformation activities can be moved out from construction sites (Vrijhoef and Koskela 2000). Most construction supply chains are highly fragmented and are connected to a temporary organization, which is composed of a large variety of companies, mostly of medium and small size (Cheng et al. 2010).

In essence, in modular supply chains, management tends to occur outside the production sites (Doran and Giannakis 2011). The degree of modularity is influenced by the degree of separation between design and execution (Voordijk et al. 2006). In an integral SC the companies are more interdependent (Voordijk, et al. 2006). By contrast, in a less integral (loosely coupled) SC, participants have less interaction (Pero et al. 2015), may be 
geographically distant, and there is no involvement in the design phase (Voordijk et al. 2006). A lean-production system usually has a highly integral SC, except for the dimension of electronic proximity (Fine, 2000). A strong supply chain integration is necessary to overcome the negative characteristics associated with modular constructions (Doran and Giannakis 2011) and the integrality-modularity of product, process, and supply chain tend to be aligned (Fine 1998).

This paper presents a Systematic Mapping Study (SMS), which aims to understand the concepts of modularity that are applicable to the construction industry, and to identify opportunities for further research on this topic, regarding the construction industry. Furthermore, an analysis was carried-out to detect possible associations between the lean philosophy and modularity. SMS provides an overview of a specified area, based on the classification and identification of relevant research contributions (Petersen et al. 2015).

\section{RESEARCH METHOD}

SMS can be regarded as a preliminary step for a Systematic Literature Review. The research method adopted for this investigation was based primarily on the guidelines for conducting SMS proposed by Petersen et al. (2015), and on the adaptations proposed by Tranfield et al. (2003) to the field of management, from which the qualitative characteristics and the predominance of case studies to understand specifics phenomena are suggested as a way to differ from the applications in the field of Medical Sciences, for example.

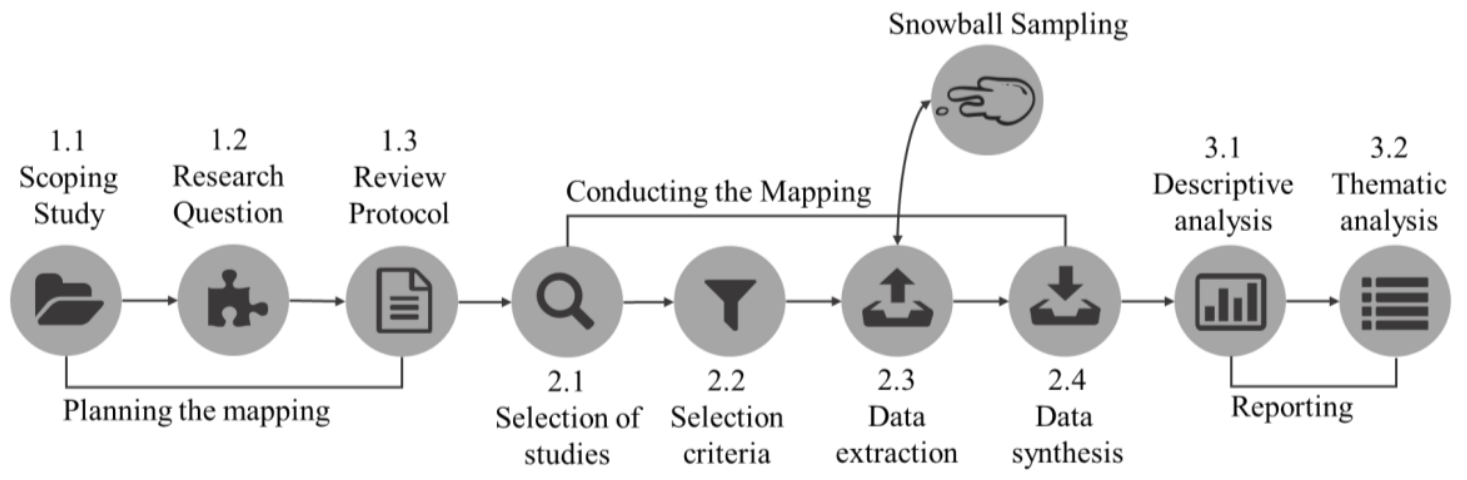

Figure 1: Research strategy

The Stage 1 (Planning the Mapping) was divided into the Scoping Study (1.1), in which the research question was defined (1.2) and the development of the Review Protocol (1.3). As a result, Stage 2 (Conducting the Mapping) consisted of the Search and Selection of Studies (2.1), applying the Selection Criteria (2.2), Data Extraction (2.3) and Synthesis (2.4). Finally, Stage 3 (Reporting) consisted of the classification and organization of evidence and was divided into two phases: Descriptive Analysis (3.1), and Thematic Analysis (3.2).

Still, between the extraction and synthesis steps, the search was complemented with a backward Snowball Sampling. This feature is indicated as an additional step for systematic mapping and literature reviews, from which new articles are added, based on the list of references or citations from an article (Wohlin 2014). The proposal in this study was to 
identify articles, through selected publications, which for some reason were not found in the search criteria, but have relevance in the field. Figure 1 presents the steps adopted in this study, which are explained in more detail in the following section

\section{RESULTS}

\section{SMS PROCEDURES}

\section{Planning the Mapping}

The initial phase was the Scoping Study, which consisted of the selection and reading of 8 papers considered to be seminal in the area by the research team. This phase was carried out with the aim of gaining greater familiarity with the theme, and also to identify the need for a systematic review and to define the research question. It included research studies from several areas related to modularity.

From the reading, the following question was defined for the SMS: "How modularity related concepts (topics) are covered in the construction industry literature?". In addition, keywords and search strings were defined, as shown in Figure 2.

\begin{tabular}{|c|c|c|}
\hline Modularity & & Context \\
\cline { 1 - 1 } $\begin{array}{c}\text { Module OR modularization OR } \\
\text { modularity }\end{array}$ & AND & $\begin{array}{c}\text { "Construction Industry" OR } \\
\text { "Building Industry" OR } \\
\text { "Building Construction" }\end{array}$ \\
\hline
\end{tabular}

Figure 2: Search String

The following step consisted in choosing the databases. Ten databases were initially listed, of which the compatibility with the theme and the availability of access were verified. From these, the following databases were chosen: (a) ScienceDirect / Elsevier; (b) Web of Science / Web of Knowledge; (c) Academic Search Complete (EBSCO); (d) Scopus and (e) Compendex.

\begin{tabular}{|l|l|}
\hline INCLUSION & EXCLUSION \\
\hline Only papers from journals & Not in the context of the construction industry \\
\hline Qualitative, quantitative and multiple methods & Systematic mappings or literature reviews \\
\hline It has to address modularity & Not Portuguese or English \\
\hline
\end{tabular}

Figure 3: Selection criteria

Regarding the review protocol, the inclusion and exclusion criteria were defined (Figure 3). The decision was made to restrict the search only to papers published in journals as a way to include a quality criterion in the classification, although, in a SMS it is not so important to apply a strict quality assessment (Petersen et al., 2015)

\section{Conducting the Mapping}

This step consisted of the execution of the research following the proposed Protocol. With the strings defined by the research team, searches were carried out at the selected databases. The files were downloaded in BibTeX format and imported into Mendeley. Also, filters were applied to limit the search to the inclusion/exclusion criteria (only papers from 
journals and in English or Portuguese) whenever the database allowed, which resulted in a substantial reduction in the number of papers for the following analysis. This study was limited to analyze only papers published in EN/PT, due to the need to understand and extract data from their main content by the authors.

The search resulted in a total of 3775 publications, from which 2149 were journal papers. Then, the selection criteria were applied, including the reading and analysis of title, abstract and keywords. Both the search for the papers and the selection criteria were performed in pairs by two members of the research team. Figure 4 shows the distribution of papers found in each database.

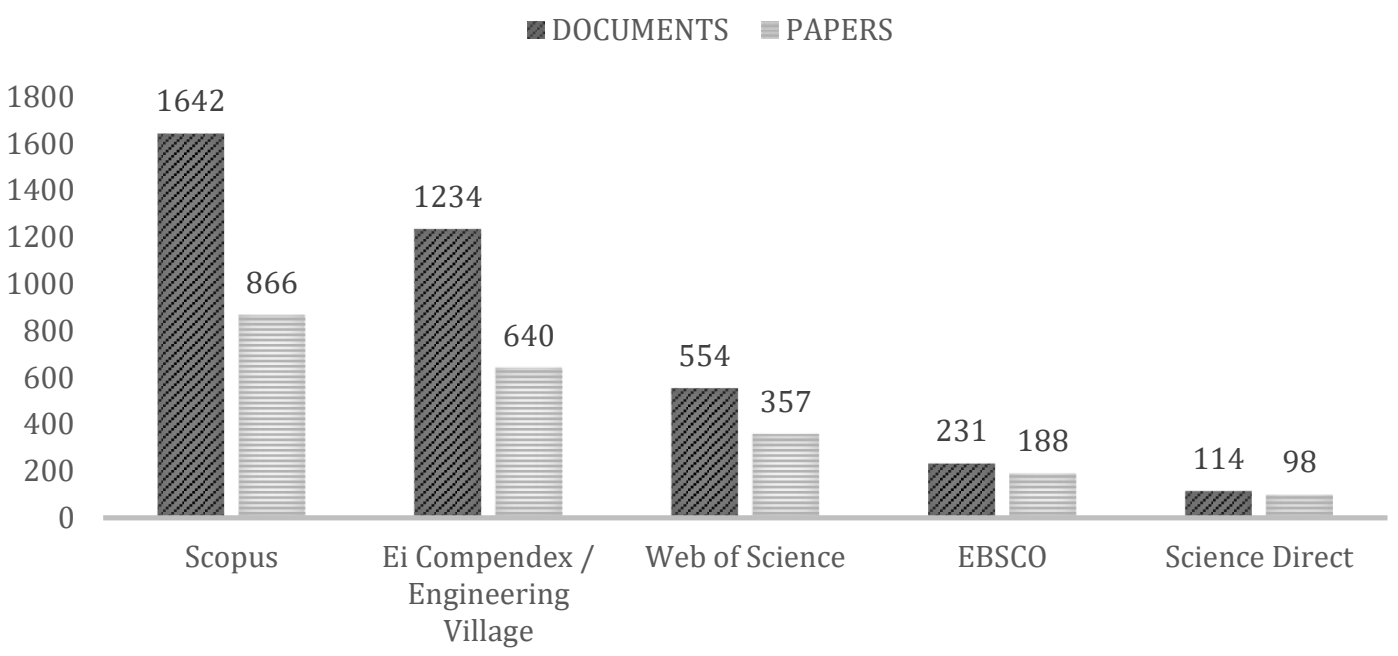

Figure 4: Database distribution

After applying the selection criteria, 236 papers were selected, from which 142 were available for reading and extracting the data.

The data extraction form was organized in Excel and contained the following parameters: Authorship, Title, Year of Publication, Journal, Authors Keywords, Method, Sample, Summary, Gaps, Country, Main Contributions, Approach Classification and Connection with Lean.

Through full-text review, 43 articles that did not meet the research criteria were rejected, and 14 articles were included through Snowball Sampling, resulting in a total of 113 papers. Table 1 summarizes the number of papers in each step of this phase.

It is observed that there was a significant reduction after the screening, resulting in about $13 \%$ of relevant papers considering the analyzed papers.

\section{Table1: Screening steps}

\begin{tabular}{ccccccc}
\hline $\begin{array}{c}\text { Papers } \\
\text { founded }\end{array}$ & $\begin{array}{c}\text { ENG / } \\
\text { PT } \\
\text { Only }\end{array}$ & $\begin{array}{c}\text { NOT } \\
\text { duplicated }\end{array}$ & $\begin{array}{c}\text { Title/abstract/Keywords } \\
\text { analysis }\end{array}$ & $\begin{array}{c}\text { Available } \\
\text { for } \\
\text { download }\end{array}$ & $\begin{array}{c}\text { Snowball } \\
\text { Sampling }\end{array}$ & $\begin{array}{c}\text { Final } \\
\text { selection }\end{array}$ \\
\hline 2149 & 1742 & 843 & 236 & 142 & 14 & 113 \\
\hline
\end{tabular}




\section{DESCRIPTIVE ANALYSIS}

Figure 5 shows the distribution of publications per year. In the 1990s until the mid2000s, few publications were found, the first being in the year of 1989. From the early 2000s, there has been a substantial increase in the number of publications. Table 2 shows the top five journals in which the papers were published, the number of papers found $(\mathrm{N})$ and the authors and year of publication. Most papers have been published in journals related to construction engineering and management.

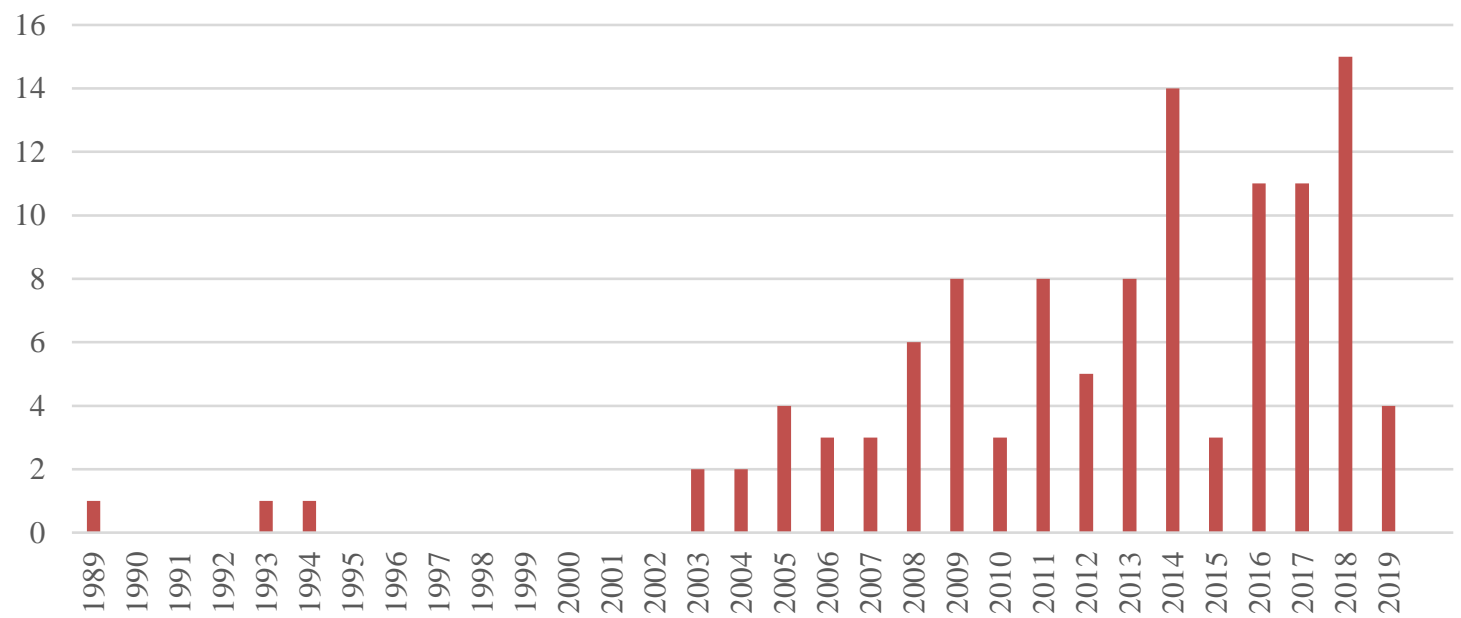

Figure 5: Distribution of relevant papers per year

Table 2: Most cited journals

\begin{tabular}{|c|c|c|}
\hline JOURNAL & $\mathbf{N}$ & PAPERS \\
\hline $\begin{array}{l}\text { Journal of Construction } \\
\text { Engineering and } \\
\text { Management }\end{array}$ & 15 & $\begin{array}{l}\text { Blacud et al. (2009); Choi et al. (2016); Dzeng et al. (2005); Dzeng } \\
\text { et al. (2004); Gill et al. (2005); Goodrum et al. (2009); Gosling et al. } \\
\text { (2016); Ikuma et al. (2011); Larsson et al. (2016); Lee and Hyun } \\
\text { (2019); Murtaza et al. (1993); Nahmens and Bindroo (2011); } \\
\text { O'Connor et al. (2014); Ramaji and Memari (2016); Song et al. } \\
\text { (2005) }\end{array}$ \\
\hline $\begin{array}{l}\text { Construction } \\
\text { Management and } \\
\text { Economics }\end{array}$ & 10 & $\begin{array}{l}\text { Agren et al. (2014); Brodetskaia et al. (2011); da Rocha and Kemmer } \\
\text { (2018); Jaillon and Poon (2010); Johnsson and Meiling (2009); } \\
\text { Meiling et al. (2014); Pan et al. (2008); Peltokorpi et al. (2018); } \\
\text { Schmidt III et al. (2014); Wikberg et al. (2014) }\end{array}$ \\
\hline $\begin{array}{l}\text { Automation in } \\
\text { Construction }\end{array}$ & 6 & $\begin{array}{l}\text { Eastman (1994); Hsu et al. (2018); Martinez et al. (2019); } \\
\text { Nasereddin et al. (2007); Olearczyk et al. (2014); Said et al. (2017) }\end{array}$ \\
\hline $\begin{array}{l}\text { Journal of Management } \\
\text { in Engineering }\end{array}$ & 6 & $\begin{array}{l}\text { Choi et al. (2019); Hall et al. (2018); Hyari and El-Rayes (2006); Liu } \\
\text { et al. (2017); Tatum (1989); Yu et al. (2013) }\end{array}$ \\
\hline $\begin{array}{l}\text { Canadian Journal of Civil } \\
\text { Engineering }\end{array}$ & 5 & $\begin{array}{l}\text { Kim et al. (2005); Li et al. (2013); Moghadam et al. (2012); Wang et } \\
\text { al. (2009); Westover et al. (2014) }\end{array}$ \\
\hline
\end{tabular}

Figure 6 shows the distribution of papers per country. Most of the studies are concentrated in the United States, followed by the United Kingdom and Australia. Canada, China, Sweden and Korea had also produced some papers. 


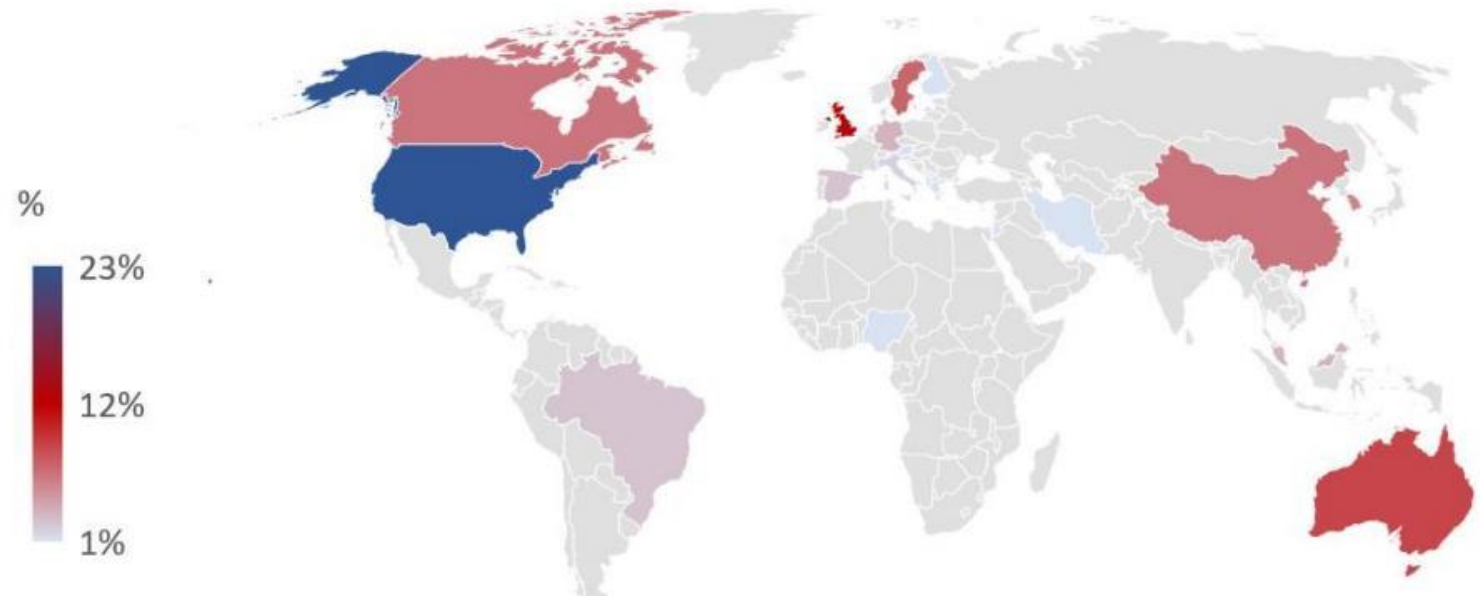

Figure 6: Distribution of papers per country

Finally, the main research methods were classified (Figure 7). Most of the papers are Case Studies, followed by Surveys. $13 \%$ of papers were found to have more than one strategy (e.g. Choi et al. (2019) carried out a literature review, a survey, and interviews). These cases were grouped as Multiple Methods. Still, 3\% of the selected articles did not make clear the methodology adopted and could not be classified.

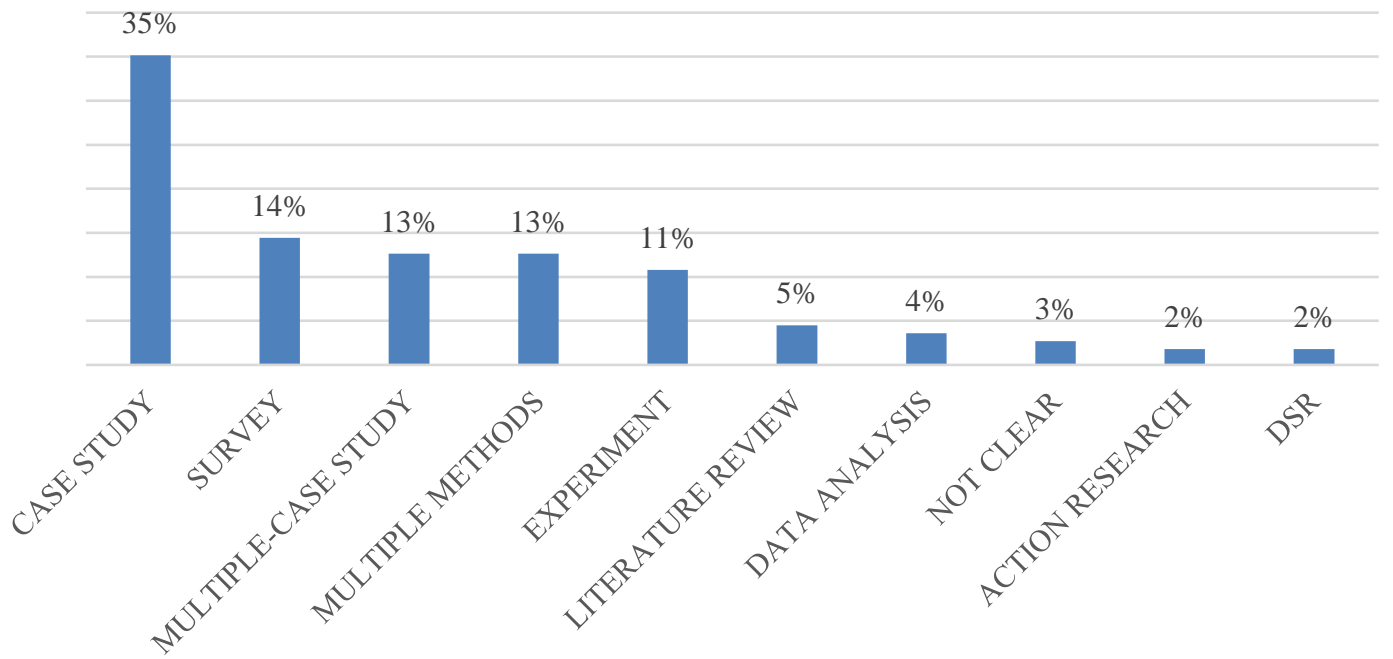

Figure 7: Research Methods

\section{THEMATIC ANALYSIS}

In order to analyse the main topic areas covered in the literature on modularity, the following classification was proposed, based on the IGLC 2019 proposed themes (Table $3)$. 
Table 3: Description of the proposed topic areas

\begin{tabular}{|c|c|}
\hline Topic Area & Description \\
\hline $\begin{array}{l}\text { Product Development and } \\
\text { Design Management }\end{array}$ & $\begin{array}{l}\text { Papers related to the development of modular products, components, or to } \\
\text { the management of the design process. }\end{array}$ \\
\hline $\begin{array}{l}\text { Contract and Cost } \\
\text { Management }\end{array}$ & $\begin{array}{l}\text { Papers related to the decision-making process, including risk analysis, } \\
\text { real estate market and stakeholders. }\end{array}$ \\
\hline $\begin{array}{l}\text { Production Planning and } \\
\text { Control }\end{array}$ & Papers related to the process of planning and control of modular projects. \\
\hline Theory & $\begin{array}{l}\text { Theoretical or literature review about modularity, including authors who } \\
\text { have identified best practices in the construction industry. }\end{array}$ \\
\hline Sustainability & $\begin{array}{l}\text { Papers related to the environmental impact of modular buildings and } \\
\text { green technologies. }\end{array}$ \\
\hline Production System Design & $\begin{array}{l}\text { Papers related to the design and execution of modular building systems, } \\
\text { including assembly techniques and automation. }\end{array}$ \\
\hline Off-Site Construction & $\begin{array}{l}\text { Papers related to the manufacturing process of modules or modular } \\
\text { component and transportation. }\end{array}$ \\
\hline $\begin{array}{l}\text { Supply Chain } \\
\text { Management }\end{array}$ & Papers related to the modular construction supply chain. \\
\hline $\begin{array}{l}\text { Safety, Quality, and } \\
\text { Health }\end{array}$ & $\begin{array}{l}\text { Papers that investigated the relationship between the use of modularity } \\
\text { and safety performance. }\end{array}$ \\
\hline Lean and BIM & $\begin{array}{l}\text { Papers that specifically addressed the use of BIM and/or Lean in modular } \\
\text { construction. }\end{array}$ \\
\hline
\end{tabular}

A total of 10 categories were proposed in order to group the diversity of topics addressed by the selected papers. This classification was made in a suggestive way by the authors. The aim of this division into categories was to identify future trends and knowledge gaps (scarce evidences). Figure 8 shows the distribution of the topics covered by previous studies. The category "Product Development and Design Management" had around $40 \%$ of the papers.

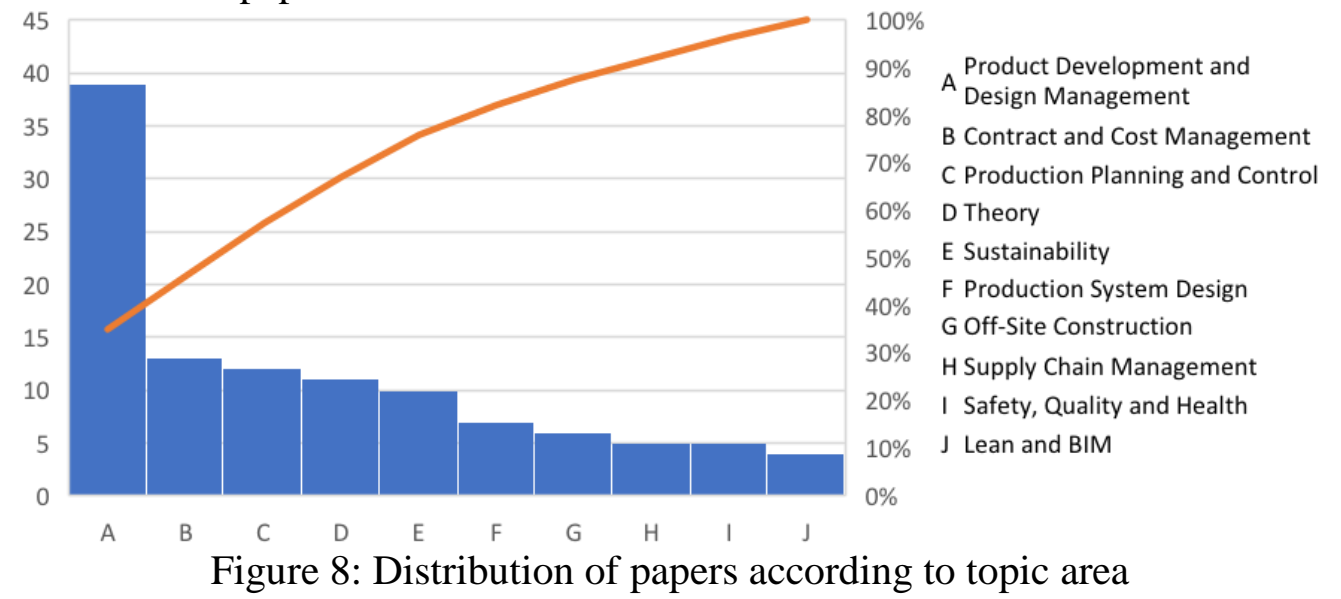

\section{LEAN PHILOSOPHY AND MODULARITY}

An analysis was made on the association between the Lean Philosophy and Modularity. The core ideas that explained that association are presented in Table 4, and these were classified in topics. 
Table 4: Core ideas that associated the Lean Philosophy and Modularity

\section{Topic Description}

Authors

\begin{tabular}{|c|c|c|}
\hline \multirow{2}{*}{ 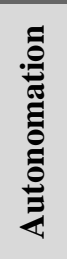 } & $\begin{array}{l}\text { Concepts of lean construction and design for manufacture and assembly, } \\
\text { enable the development of modular products by robotics systems onsite. }\end{array}$ & $\begin{array}{l}\text { Martinez et al } \\
(2008)\end{array}$ \\
\hline & A higher automation level is desirable to increase the productivity level. & $\begin{array}{l}\text { Martinez et al } \\
(2008) \\
\text { Orlowski et al } \\
(2018)\end{array}$ \\
\hline \multirow{3}{*}{ 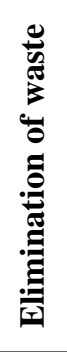 } & $\begin{array}{l}\text { Big modules transportation and assembly offsite are a significant waste of } \\
\text { space, against lean philosophy. Production like kit-of-parts and onsite } \\
\text { assembly in temporary factories can reduce waste of time and space of big } \\
\text { modules. }\end{array}$ & $\begin{array}{l}\text { Martinez et al } \\
(2008)\end{array}$ \\
\hline & $\begin{array}{l}\text { Consumer-oriented approaches in which quality and value for money drive } \\
\text { the requirements to reorganize production. }\end{array}$ & $\begin{array}{l}\text { Barlow et al } \\
(2003)\end{array}$ \\
\hline & $\begin{array}{l}\text { On-site re-design, waste costs, time savings can be achieved by the design of } \\
\text { products to be manufactured and assembled during the design stage. }\end{array}$ & $\begin{array}{l}\text { Martinez et al } \\
(2013)\end{array}$ \\
\hline \multirow{4}{*}{$\frac{2}{\frac{2}{0}}$} & $\begin{array}{l}\text { Improvements in quality and meet the individual needs of different customers } \\
\text { have been driven by consumer-oriented approaches. }\end{array}$ & $\begin{array}{l}\text { Barlow et al } \\
(2003)\end{array}$ \\
\hline & $\begin{array}{l}\text { Lean production is applied to the design of new materials and products with } \\
\text { different levels of finishing that make modular assembly possible. The design } \\
\text { of new materials and products with different finishing are enabled by } \\
\text { concepts related to lean production, making modular assembly possible. }\end{array}$ & $\begin{array}{l}\text { Martinez et al } \\
(2008)\end{array}$ \\
\hline & $\begin{array}{l}\text { There are high levels of customization in buildings, making building modules } \\
\text { one of a kind, this variety can be supported by lean principles. }\end{array}$ & Yu et al (2013) \\
\hline & $\begin{array}{l}\text { Ease of training, ease of change, paced implementation and the opportunity } \\
\text { for strategic alignment would seem to dominate processing efficiency and } \\
\text { consistency arguments of large-scale ERP proponents. }\end{array}$ & $\begin{array}{l}\text { Arif et al } \\
(2011)\end{array}$ \\
\hline \multirow{6}{*}{ Uूँ } & $\begin{array}{l}\text { Carry out an extended analysis which investigates the impact modularization } \\
\text { has on other organizational initiatives such as lean. }\end{array}$ & $\begin{array}{l}\text { Hvam et al } \\
(2017)\end{array}$ \\
\hline & $\begin{array}{l}\text { Full implementation of Lean in the industrialized housing industry may } \\
\text { further improve processes in terms of both efficiency and safety. }\end{array}$ & $\begin{array}{l}\text { Nahmens and } \\
\text { Ikuma (2009) }\end{array}$ \\
\hline & $\begin{array}{l}\text { Construction practitioners argue that construction is distinct from auto } \\
\text { manufacturing and that lean production is not applicable. The research } \\
\text { approaches lean focusing on balancing the production line process stability } \\
\text { rather than improving productivity }\end{array}$ & Yu et al (2013) \\
\hline & $\begin{array}{l}\text { Offsite prefabrication/preassembly depends on the lean concept of moving } \\
\text { the work to the workers in a controlled production environment. }\end{array}$ & $\begin{array}{l}\text { Said et al } \\
(2017)\end{array}$ \\
\hline & $\begin{array}{l}\text { Relates the lean principles and techniques, such as standardized work and } \\
\text { visual management to organize the workplace in construction. }\end{array}$ & Yu et al (2013) \\
\hline & $\begin{array}{l}\text { Utilize simulation as a decision tool to assist the design of a new factory to } \\
\text { incorporate lean principles as flexibility, responsivity and efficiency. }\end{array}$ & $\begin{array}{l}\text { Nasereddin et } \\
\text { al (2007) }\end{array}$ \\
\hline \multirow{3}{*}{ 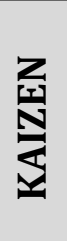 } & $\begin{array}{l}\text { The case study applies the lean production tool, Kaizen, in a modular housing } \\
\text { manufacturing facility. }\end{array}$ & $\begin{array}{l}\text { Ikuma et al } \\
(2011)\end{array}$ \\
\hline & Evaluates the impact of Kaizen in workers safety at a modular homebuilder. & $\begin{array}{l}\text { James et al } \\
(2014)\end{array}$ \\
\hline & $\begin{array}{l}\text { 5S proved to be an effective way to get people involved in lean initiatives and } \\
\text { enthused about lean by realizing immediate results. }\end{array}$ & Yu et al (2013) \\
\hline
\end{tabular}


Table 4 (cont.): Core ideas that associated the Lean Philosophy and Modularity

\begin{tabular}{l|l|l} 
Topic & Description & Authors \\
\hline \multirow{2}{*}{} & $\begin{array}{l}\text { A set of lean principles are used to reduce waste over a range of factory } \\
\text { activities. It is proposed a modularization production method to improve } \\
\text { modular factory production flow based on work activity relationship. }\end{array}$ & $\begin{array}{l}\text { Lee et al } \\
(2017)\end{array}$ \\
\hline \multirow{2}{*}{} & $\begin{array}{l}\text { Relates large-scale lean efficiencies in the design and construction process to } \\
\text { sustainability. }\end{array}$ & $\begin{array}{l}\text { Zakaria et al } \\
(2018)\end{array}$ \\
\cline { 2 - 3 } & Management based on lean principles optimize carbon emission. & $\begin{array}{l}\text { Gong et al } \\
(2015)\end{array}$ \\
\cline { 2 - 3 } & $\begin{array}{l}\text { By improving the delivery process of modular houses, lean strategies } \\
\text { improve the economic, social and environmental dimensions. }\end{array}$ & $\begin{array}{l}\text { Nahmens and } \\
\text { Ikuma (2011) }\end{array}$ \\
\hline
\end{tabular}

There are different approaches involving the Lean Philosophy and Modularity. To summarize the different lean concepts related to modularity examined by the papers, the ideas presented by the authors were classified into topics, as proposed in Table 4 . Of the 113 papers, 34 mention lean principles (30\%), although only $19 \%$ specifically related lean principle to modularity.

From the analysed papers, lean principles are mainly associated to efficiency in modular construction. It is associate to improvements in production through autonomation (Martinez et al. 2008; Orlowski et al. 2018; Yu et al. 2013), Kaizen (Lee et al. 2017; Ikuma et al. 2011; James et al, 2014; Yu et al, 2013) and flexibility (Barlow et al, 2003; Martinez et al, 2008; Yu et al. 2013; Arif et al. 2011). Authors also link some design process improvements in modular construction to lean: flexibility enables the design of new materials and products (Martinez et al. 2008) and reduction of waste reduces re-design (Martinez et al. 2013). Authors also bring customization, one of a kind modules (Yu et al. 2013) and customer oriented-approach (Barlow et al, 2003) as strategies supported by lean concepts as flexibility (Yu et al. 2013). Other general aspects from lean philosophy are pointed out as enablers of modularization as standardized work, visual management (Yu et al. 2013) and responsivity (Nasereddin et al. 2007).

\section{CONCLUSIONS}

This paper presents the results of a SMS regarding modularity in the construction industry, as a preliminary stage of a future Systematic Literature Review effort. The purpose of this study was to identify the primary areas covered by the existing literature and, in addition to, identify the relationship of those studies with Lean Philosophy.

In response to the stated research question, the conclusion was made that most of the papers selected were related to the development of modular products. However, this category involves a great diversity of aspects, since it encompassed both the design process and the development of modules or modular components.

Regarding the Lean Philosophy, only $19 \%$ of the papers properly explained the connection of modularity and Lean, although intrinsic characteristics of lean production systems can be found in several papers. The aforementioned Lean topics were grouped into the following proposed categories: (a) Sustainability; (b) Autonomation; (c) Elimination of waste; (d) Flexibility; (e) Kaizen and (f) General.

The next steps of this research will deepen the literature review, identifying the main contributions of these research studies and possible gaps. 


\section{REFERENCES}

Cheng, J. C., Law, K. H., Bjornsson, H., Jones, A., and Sriram, R. (2010). "A service oriented framework for construction supply chain integration." Automation in construction, 19(2), 245-260.

Choi, J. O., O'Connor, J. T., and Kim, T. W. (2016). "Recipes for Cost and Schedule Successes in Industrial Modular Projects: Qualitative Comparative Analysis.” Journal of Construction Engineering and Management, 142(10), 04016055.

Da Rocha, C. G. (2011) "A conceptual framework for defining customisation strategies in the house- building sector. "Porto Alegre, 2011. Thesis (Ph.D. in Engineering) - Escola de Engenharia, Programa de Pós-Graduação em Engenharia Civil, UFRGS, Porto Alegre.

Doran, D., and Giannakis, M. (2011). "An examination of a modular supply chain: a construction sector perspective." Supply Chain Management: An International Journal, 16(4), 260-270.

Fine, C. H. (2000). "Clockspeed-based strategies for supply chain design." Production and operations management, 9(3), 213-221.

Fine, C. H. (1998). “Clockspeed: using business genetics to evolve faster than yourcompetitors." Little, Brown and Company, London.

Gershenson, J. K., Prasad, G. J., and Zhang, Y. (2003). "Product modularity: Definitions and benefits." Journal of Engineering Design, 14(3), 295-313.

Gosling, J., Pero, M., Schoenwitz, M., Towill, D., and Cigolini, R. (2016). "Defining and Categorizing Modules in Building Projects: An International Perspective.” Journal of Construction Engineering and Management, 142(11), 04016062.

Kitchenham, B. (2004). "Procedures for Performing Systematic Reviews.". Keele, UK, Keele University, 33, 1-26.

Lennartsson, M., and Björnfot, A. (2010). "Step-by-step modularity - A roadmap for building service development." Lean Construction Journal, Lean Construction Institute, 2010, 17-29.

Lessing, Jerker. (2006).“Industrialised house-building. Concept and Processes."

Miller, T. D. and Elgård, P. (1998). "Defining Modules, Modularity and Modularization." Proceedings of the ASME Design Engineering Technical Conference.

Moghadam, M., Al-Hussein, M., Al-Jibouri, S., and Telyas, A. (2012). "Post simulation visualization model for effective scheduling of modular building construction." Canadian Journal of Civil Engineering, 39(9), 1053-1061.

Peltokorpi, A., Olivieri, H., Granja, A. D., and Seppänen, O. (2018). "Categorizing modularization strategies to achieve various objectives of building investments." Construction Management and Economics, 36(1), 32-48.

Pero, M., Stößlein, M., \&Cigolini, R. (2015). "Linking product modularity to supply chain integration in the construction and shipbuilding industries." International Journal of Production Economics, 170, 602-615.

Petersen, K., Vakkalanka, S., \&Kuzniarz, L. (2015). “Guidelines for conducting systematic mapping studies in software engineering: An update." Information and Software Technology,64, 1-18. 
Simon, H. A. (1991)“The architecture of complexity. In: Facets of systems science." Springer, Boston, MA. p. 457-476.

Schilling, M. A. (2000) "Toward a general modular systems theory and its applicationto interfirm product modularity". Academy of management review, v. 25, n. 2, p. 312-334.

Tranfield, D., Denyer, D., and Smart, P. (2003). "Towards a methodology for developing evidence-informed management knowledge by means of systematic review". 14, 207222.

Viana, D. D.; Tommelein, I. D.; Formoso, C. T. (2016) Using modularity toreduce complexity of industrialized construction projects: a case study. In: ZEMCH2016 International Conference, Kuala Lumpur. ZEMCH 2016 InternationalConference.

Voordijk, H., Meijboom, B., \& de Haan, J. (2006). "Modularity in supply chains: a multiple case study in the construction industry. "International journal of operations \& production management, 26(6), 600-618.

Vrijhoef, R., \&Koskela, L. (2000). "The four roles of supply chain management in construction. "European journal of purchasing \& supply management, 6(3-4), 169-178.

Wohlin, C. (2014). "Guidelines for Snowballing in Systematic Literature Studies and A Replication in Software Engineering.". In Proceedings of the 18th International Conference on Evaluation and Assessment in Software Engineering. p. 38. 